\title{
A Study of the Use of Cashless Payments in Relation to Income, Financial Behavior, and Almsgiving Behavior in Sumatera, Indonesia
}

\author{
Khaira Amalia Fachrudin ${ }^{1, *}$ Amlys Syahputra Silalahi ${ }^{2}$ \\ ${ }^{1,2}$ Faculty of Economics and Business, Universitas Sumatera Utara \\ Email: khaira@usu.ac.id
}

\begin{abstract}
In 2014, Bank Indonesia established the National Non-Cash Movement. Cashless payments are made digitally for changing financial transactions among people. This study aims to investigate whether gender, income, herding behavior in shopping, debt behavior, and almsgiving behavior affect the opportunities for using cashless payments in Sumatra, Indonesia. The sample consists of 500 people who come from five major cities in Sumatra, including Medan, Batam, Palembang, Padang, and Lampung. Logistic regression was used as the analytical tool. The results of the present study revealed that at alpha five percent, income and herding behavior in shopping had an effect on the use of cashless payments. The implication is that the use of cashless payments can be promoted through increasing the community income so that it can increase economic growth and efficiency at the same time. However, herding behaviour should not be excessively exercised despite it can increase the use of non-cash transactions.
\end{abstract}

Keywords: Almsgiving behavior, cashless payments, financial behavior, herding behavior, income

\section{INTRODUCTION}

Technological developments cause changes in all aspects of human life, including the payment system. Cash-based payment method has transformed into cashbased payment method has transformed into non-cash payment. The digitalization of the payment method will be regarded as a watershed moment in the future economy's cashless era [1]. Bank Indonesia also promoted the Non-Cash Movement (GNNT) campaign on August 14, 2014.

Electronic transactions in Indonesia have seen a rapid growth from 2015 to 2020 as illustrated in Table 1. For the year 2021, up to July, the amount reached Rp. 157,415,340.67.

Table 1. Electronic Transactions in Indonesia

\begin{tabular}{|c|c|}
\hline Periods & Amount (IDR 000,000) \\
\hline Year 2015 & $5,283,017.65$ \\
\hline Year 2016 & $7,063,688.97$ \\
\hline Year 2017 & $12,375,468.72$ \\
\hline Year 2018 & $47,198,616.11$ \\
\hline Year 2019 & $145,165,467.60$ \\
\hline Year 2020 & $204,909,170.02$ \\
\hline
\end{tabular}

Source : Bank Indonesia, 2021
Cashless payments are dominantly done by people with higher education backgrounds and higher material status [2].

The pandemic has caused landslide changes in consumer behavior and habits. Prior to pandemic, the people in Poland were not interested in opting for cashless payments, but their perception of the risks posed by Covid-19 has led to an increase in the use of cashless payments [3]. A number of previous research have largely examined performance, convenience in cashless payment, and lifestyle. For example, [4] found that performance expectancy, perceived technology security, condition, hedonic motivation, innovativeness, and social influence are positively related to the adoption of cashless payments. [5] discovered that the ease of use, innovativeness, usefulness, optimism and lack of awareness have a direct effect on users' readiness to use non-cash transactions. The research conducted by [6] in Indonesia found that lifestyle significantly influences the intention to use e-wallet.

Another previous research examined the difference between age, education, residence location and the choice of payment [7]. The youngest (aged 15-24) and 
the oldest (aged 60 and above) have the lowest banking adoption rates, indicating that cashless payments were not natural from the start and that they still use cash. Education is not the factor that contributes to the use of cashless payment. People who live in the suburbs of medium and big cities and work in big cities use cashless more.

The present study is relatively new compared to the previous studies. The present study seeks to examine the effect of individual characteristics and behavior on the probability of using cashless payment. The characteristics of the individual under examination include gender and income, while the behavior under examination includes herding behavior in shopping, debt behavior, and almsgiving behavior.

Shopping behavior, especially the copycat shopping behavior, might boost the use of non-cash payment, thus it is assumed that herding behavior in shopping has the potential to increase non-cash payment. The notion 'pain of paying' has it that a person experiencing certain emotion when paying with money physically, they feel sick psychologically [8].

Debt behavior is the individual behavior related to debt level, debt to income ratio and debt management [9]. Uncontrolled debt behavior might lead to financial distress experienced by an individual. This debt behavior might get worse if an individual has a credit card.

At present, there are Charitable Institutions opening up accounts for charity collection purpose. Typically, the donors will transfer their donation to the Institution. Based on this notion, we proposed a hypothesis maintaining that almsgiving behavior has the potential to increase non-cash payment system.

The notion 'pain of paying' argues that a person experiencing certain emotion when paying for money physically, they feel sick psychologically [8]. With cashless payment, the suffering is gone as someone does not have to spend out money. Thus, it is assumed that shopping behavior, debt and almsgiving with cashless payment are correlated.

There are ten major big cities in Indonesia, including Jakarta, Semarang, Surabaya, Medan, Bandung, Makassar, Bandar Lampung, Palembang, Padang, dan Batam. Five of these, including Medan, Palembang, Bandar Lampung, Batam, and Padang, are located on Sumatera. These five cities in Sumatra are categorized as cities with an advanced economy and have high noncash transaction level.

The present study aims at discovering empirical evidence of the impact of gender, income, herding behavior in shopping, debt behavior, and almsgiving behavior on cashless payments potentials in Sumatra,
Indonesia. The urgency of this research is that it creates a new perspective on the factors which affect cashless payment. The benefit of the present research is to help create a policy for promoting a Non-Cash Movement nationwide. In addition, for corporation, particularly its marketing division, this study might shed some lights on the strategy for selling goods online.

\section{LITERATURE REVIEW}

A cashless payment is one in which financial transactions are made using digital currencies rather than cash. In cashless payments, consumers conduct transactions without using money, primarily through the use of cards or electronic methods [4] and mobile payment [7]. For example, credit cards, debit cards, check, bilyet giro (transfer form), credit notes, debit notes, e-money, internet banking, e-wallet, mobile wallet, and other online transfers.

\subsection{Financial behavior}

Financial behavior is human actions related to their financial settings [10]. [11]divided financial behavior into 4 sub-factors, including savings, investment, as well as cash and credit management. However, [10] and [11] add another factor of retirement planning and insurance.

[14] found a financial management behavior scale ranging from 1 to 5 , starting from never, seldom, sometimes, often, and always. It concerns with making a comparison when making a purchase of a product or service, paying bills on time, and making notes on monthly expenses. Morever, the statement on staying within budget or initial spending plan, maximize credit card limits, paying credit, saving for long-term goals such as education, owning a car and house, and having an emergency savings fund was also put forth by [14]. Furthermore, the statement comprises depositing money into a retirement account, buying bonds, stocks, or mutual funds, and having adequate health, property, and insurance policies.

The indicators of financial behavior include comparing prices in different stores when it comes to purchasing products or services, as well as paying bills on time. Other indicators are recording monthly expenses and staying within planned budget and paying off overdraft balance every month. Furthermore, there are indicators of exceeding the ATM card's maximum withdrawal limit and paying more than the minimum loan payment. Others include establishing or maintaining an emergency savings fund, saving for long-term goals, contributing to a retirement account, and purchasing bonds, stocks, mutual funds, or long-term investments, car insurance, and life insurance [15]. 


\subsection{Debt Behavior}

Debt behavior is the financial knowledge or financial literacy in managing money [16]. This knowledge is needed so that individuals can manage their debts so that financial well-being can be achieved [17]. According to [9], one of the debt behaviors is shown by the feeling of discomfort by borrowers with their debt. Furthermore, people who are unhappy with their debt have lower debtto-income ratios.

\subsection{Amlsgiving behavior}

Almsgiving is a combination of two completely different words from English : as spiritual love and as an alms [16]. In Islam, Judaism, and Christianity, it is emphasized that all wealth belongs to God and not to us.

In Islam, zakat and alms funds are collected by nonprofit institutions. These non-profit organizations then donate these funds to provide food, scholarships, charity caravans, income-generating projects and most importantly to help the orphans [19].

\section{METHOD}

The sample consists of 500 people who came from the five largest major cities in Sumatera, namely Medan, Batam, Palembang, Padang, and Lampung. The analytical tool used is logistic regression.

Binary regression model

$\mathrm{y}_{1 \mathrm{t}}=\mathrm{a}+\mathrm{b}_{1} \mathrm{x}_{1 \mathrm{it}}+\mathrm{b}_{2} \mathrm{x}_{2 \mathrm{it}}+\ldots+\mathrm{b}_{5} \mathrm{x}_{5 \mathrm{it}}+\mu$

Descended into logistics distribution function $\mathrm{P}_{\mathrm{it}}=1 /\left[1+\exp \left(\mathrm{a}+\mathrm{b}_{1} \mathrm{x}_{1 \mathrm{it}}+\mathrm{b}_{2} \mathrm{x} 2_{\mathrm{it}}+\ldots \mathrm{b}_{5} \mathrm{x}_{5 \mathrm{it}}+\right)\right]$

$\mathrm{P}_{\text {it }}=$ probability of non-cash payment with value between 0 and 1

$\mathrm{Y}=1$ for cashless payment greater than $50 \%, 0$ other than that

$\mathrm{X}_{1}=$ Gender

$\mathrm{X}_{2}=$ Income

$\mathrm{X}_{3}=$ Herding behavior in Shopping

$\mathrm{X}_{4}=$ Debt behavior

$\mathrm{X}_{5}=$ Alms giving behavior

\section{RESULTS AND DISCUSSION}

\subsection{Logistic Regression Test Results}

Logistic Regression Test Results are in appendix

Model Coefficients Omnibus Test

The overall model fit which is measured using omnibus test statistics employs a chi-square test. If the pvalue of the omnibus test statistic is less than the aplpha, the null hypothesis is rejected. All models developed in this study have a lower significance than the alpha (0.05), indicating that they are consistent with the data.

Nagelkarke $R^{2}$

The variability of independent variables explained by dependent variables is explained by Nagelkarke R2. The study produced R2 at $18.9 \%$. Despite small, this finding provides answers to the research's questions.

Hosmer and Lemeshow Test

The Hosmer-Lemeshow goodness-of-fit statistic is used to evaluate the model's fit for the purpose of comparing the predicted and actual values of the dependent variable. Figures which are greater than alpha indicate that the model can be adopted for further analysis as the predicted and the observed classifications have no significant differences. The results of the test generate Hosmer and Lemeshow value of 0.268 , which is bigger than alpha $1 \%$.

-2 Log Likelihood

The number -2LL (Deviance, DEV, or D) compares the observed probability with the predicted probability. The Log-Likelihood value from the model shows that they are compatible with the data. The test results showed a decline of 418,335 from the base model - greater than critical values table of chi square.

Classification Tables

The classification table is used to measure the prediction accuracy of multivariate logistic regression models. This model, in this study, generated a relatively higher classification capacity by $82.2 \%$.

The test results indicated that income $\left(\mathrm{X}_{2}\right)$ dan herding behavior in shopping $\left(\mathrm{X}_{3}\right)$ have the potential to boost cashless payment significantly. Whereas, gender $\left(\mathrm{X}_{1}\right)$, debt behavior $\left(\mathrm{X}_{4}\right)$, and almsgiving behavior $\left(\mathrm{X}_{5}\right)$ have the potential to boost cashless payment use insignificantly. People with high income generally have internet banking facilities and have large amount of needs leading to the major use of cashless payment. People with copycat behavior in shopping, especially online shopping, are used to cashless payment as online shopping typically requires cashless payment in its online transaction. 
This finding is in line with [20] which suggests that there is a negative arousal that arises when someone pays in cash. When he makes a cashless payment this negative arousal is reduced, and thus atrracts less attention to decision risk. Therefore, cashless payments can increase risky consumption behavior. Emotion was especially felt that during physically paying money [8] was not felt by spending time following it was done online.

The impact of debt behavior on cashless payment in this study is found to be insignificant. It can be said that debt behavior of the respondents in this study is within reasonable limit as it does not significantly affect cashless payment. This finding is congruent with [21] who argue that risky debt practices may result from improper use of credit cards that traps the consumers into consumptive behaviors. It also supported by [22] which revealed that consumers spend more time using credit card by up to $100 \%$ [23].

Almsgiving behavior also does not have the significant potential to boost cashless payment use. This means that the charity transaction is not entirely made by cashless payment. In fact, nowadays, the use of digital transactions has been widely adopted by the zakat management [24].

\section{CONCLUSIONS}

The results showed that at alpha five percent of income and herding behavior in shopping had an effect on the use of cashless payments. The implication is that the use of cashless payments can potentially increase through increasing community income so it can increase economic growth and efficiency. However, herding behavior should not be excessively done despite its ability to boost the use of non-cash transactions.

\section{AUTHORS' CONTRIBUTIONS}

Each author has an equal contribution in writing this paper.

\section{ACKNOWLEDGMENTS}

The authors acknowledged that the present research is funded by the Directorate of Research and Community Service of the Ministry of Research and Technology / Research and Technology / National Research and Innovation Agency for the Fiscal Year of 2021 under the Research and Community Service Funding Agreement for the Fiscal Year 2021, with contract number 12/EI/KP.PTNBH/2021, March 8, 2021

\section{REFERENCES}

[1] F. Thirupathi, G. Vinayagamoorthi, and S. P. Mathiraj, "Effect of cashless payment methods:
A case study perspective analysis," International Journal of Scientific and Technology Research, vol. 8, no. 8, 2019.

[2] B. Świecka, "Financial literacy as a factor of cashless payments development. Results of survey," European Journal of Service Management, vol. 27, 2018, doi: 10.18276/ejsm.2018.27/2-57.

[3] M. Kulisz, A. Bojanowska, and K. Toborek, "Consumer's Behaviour Regarding Cashless Payments during the Covid-19 Pandemic," EUROPEAN RESEARCH STUDIES JOURNAL, vol. XXIV, no. Special Issue 2, 2021, doi: $10.35808 /$ ersj/2224.

[4] M. Rahman, I. Ismail, and S. Bahri, "Analysing consumer adoption of cashless payment in Malaysia," Digital Business, vol. 1, no. 1, 2020, doi: 10.1016/j.digbus.2021.100004.

[5] V. Balakrishnan and N. L. M. Shuib, "Drivers and inhibitors for digital payment adoption using the Cashless Society Readiness-Adoption model in Malaysia," Technology in Society, vol. 65, 2021, doi: 10.1016/j.techsoc.2021.101554.

[6] M. Yang, A. al Mamun, M. Mohiuddin, N. C. Nawi, and N. R. Zainol, "Cashless transactions: A study on intention and adoption of e-wallets," Sustainability (Switzerland), vol. 13, no. 2, 2021, doi: 10.3390/su13020831.

[7] B. Świecka, P. Terefenko, T. Wiśniewski, and J. Xiao, "Consumer financial knowledge and cashless payment behavior for sustainable development in poland," Sustainability (Switzerland), vol. 13, no. 11, 2021, doi: 10.3390/su13116401.

[8] O. Zellermayer, "The pain of paying.," 1997.

[9] J. Almenberg, A. Lusardi, J. Säve-Söderbergh, and R. Vestman, "Attitudes Toward Debt and Debt Behavior," Cambridge, MA, Aug. 2018. doi: $10.3386 /$ w24935.

[10] H. K. Baker and J. R. Nofsinger, Behavioral Finance: Investors, Corporations, and Markets. 2011. doi: 10.1002/9781118258415.

[11] M. A. Hilgert, J. M. Hogarth, and S. G. Beverly, "Household Financial Management: The Connection between Knowledge and Behavior," Fed. Res. Bull, vol. 89, pp. 309-undefined, 2003.

[12] L. Farrell, T. R. L. Fry, and L. Risse, "The significance of financial self-efficacy in explaining women's personal finance 
behaviour," Journal of Economic Psychology, vol. 54, Jun. 2016, doi: 10.1016/j.joep.2015.07.001.

[13] W. Vosloo, J. Fouche, and J. Barnard, "The Relationship Between Financial Efficacy, Satisfaction With Remuneration And Personal Financial Well-Being," International Business \& Economics Research Journal (IBER), vol. 13, no. 6, 2014, doi: 10.19030/iber.v13i6.8934.

[14] J. Dew and J. J. Xiao, "The Financial Management Behavior Scale: Development and Validation," Journal of Financial Counseling and Planning, vol. 7, no. 10, pp. 43-59, 2013.

[15] M. Oquaye, G. M. Y. Owusu, and G. A. Bokpin, "The antecedents and consequence of financial well-being: a survey of parliamentarians in Ghana," Review of Behavioral Finance, 2020, doi: 10.1108/RBF-12-2019-0169.

[16] K. Jamilakhon, J. S. K. Singh, A. Subramaniam, and S. Suppramaniam, "Determinants of debt behavior. A quantitative study among generation $\mathrm{Y}$ individuals in Tashkent, Uzbekistan," Test Engineering and Management, vol. 82, no. 1-2, 2020 .

[17] S. Braunstein and C. Welch, "Financial Literacy: An Overview of Practice, Research, and Policy," Federal Reserve Bulletin , 2002.

[18] G. Agustin, A. Sumanto, M. Hasyim Ibnu Abbas, L. Fajar Prastiwi, and S. Merlinda, "Alms-Giving and Financial Management," KnE Social Sciences, Apr. 2020, doi: 10.18502/kss.v4i7.6864.

[19] J. Benthall, “The Qur'an's Call to Alms. Zakat, the Muslim Tradition of Alms-giving," ISIM, Leiden, vol. 1, no. 1, pp. 12-13, 1998.

[20] J. Park, C. Lee, and M. Thomas, "Why do cashless payments increase unhealthy consumption? The decision-risk inattention hypothesis," Journal of the Association for Consumer Research, vol. 6, no. 1, 2021, doi: 10.1086/710251.

[21] J. Cloutier and A. Roy, "Consumer Credit Use of Undergraduate, Graduate and Postgraduate Students: An Application of the Theory of Planned Behaviour," Journal of Consumer Policy, vol. 43, no. 3, 2020, doi: 10.1007/s10603019-09447-8.

[22] B. Hardekopf, "Do people really spend more with credit cards? ," Forbes, Jul. 16, 2018.
[23] S. Kumar, "Intention to Use Credit Card among College Students in Greater Jakarta," JAAF (Journal of Applied Accounting and Finance, vol. 4, no. 1, 2020.

[24] P. Kharisma and P. Y. Jayanto, "Faktor-Faktor yang Mempengaruhi Minat Menggunakan EZakat dalam Membayar Zakat, Infaq, dan Sedekah ," Akses : Jurnal Ekonomi dan Bisnis, vol. 16, no. 1, pp. 47-56, 2021.

\section{APPENDIX}

Omnibus Tests of Model Coefficients

\begin{tabular}{|l|l|r|r|r}
\hline \multicolumn{2}{|c|}{} & Chi-square & df & \multicolumn{1}{c}{ Sig. } \\
\hline \multirow{3}{*}{ Step 1} & Step & 62,018 & 5 &, 000 \\
\cline { 2 - 5 } & Block & 62,018 & 5 &, 000 \\
\cline { 2 - 5 } & Model & 62,018 & 5 &, 000 \\
\hline
\end{tabular}

Model Summary

\begin{tabular}{|l|r|r|r|}
\hline Step & $\begin{array}{c}-2 \text { Log } \\
\text { likelihood }\end{array}$ & $\begin{array}{c}\text { Cox \& Snell } \\
\text { R Square }\end{array}$ & $\begin{array}{c}\text { Nagelkerke } \\
\text { R Square }\end{array}$ \\
\hline 1 & $418.353^{\mathrm{a}}$ &, 117 &, 189 \\
\hline
\end{tabular}

a. Estimation terminated at iteration number 5

Hosmer and Lemeshow Test

\begin{tabular}{|c|c|c|c|}
\hline Step & $\begin{array}{l}\text { Chi- } \\
\text { square }\end{array}$ & $\mathrm{df}$ & Sig. \\
\hline 1 & 9,962 & 8 & ,268 \\
\hline
\end{tabular}

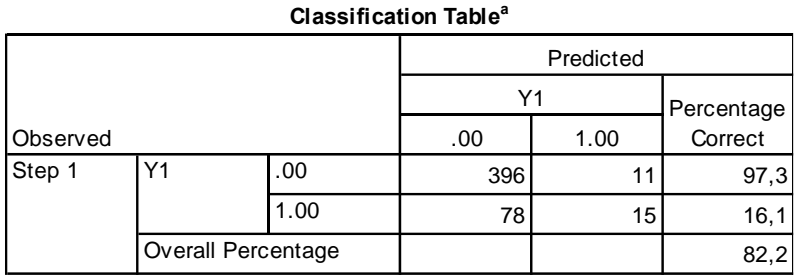

\begin{tabular}{|c|c|c|c|c|c|c|c|}
\hline \multicolumn{8}{|c|}{ Variables in the Equation } \\
\hline & & $B$ & S.E. & Wald & $d f$ & Sig. & $\operatorname{Exp}(B)$ \\
\hline \multirow[t]{6}{*}{ Step $1^{\mathrm{a}}$} & $\mathrm{X} 2$ &, 520 & ,077 & 46,044 & 1 & 000 & 1,682 \\
\hline & $\overline{x 3}$ &, 323 & 129 & 6,294 & 1 & 012 & 1,381 \\
\hline & $\mathrm{X} 4$ & 054 & 161 &, 114 & 1 &, 735 & 1,056 \\
\hline & $\times 5$ & ,131 & ,171 & ,593 & 1 & ,441 & 1,140 \\
\hline & $\mathrm{X} 1$ & ,224 & ,254 & ,777 & 1 & ,378 & 1,251 \\
\hline & \begin{tabular}{|l|} 
Constant \\
\end{tabular} & $-4,726$ & 1,037 & 20,784 & 1 & ,000 & 009 \\
\hline
\end{tabular}

